\title{
Changing distribution patterns of canine vector borne diseases in Italy: leishmaniosis vs. dirofilariosis Domenico Otranto $^{1 * \S}$, Gioia Capelli ${ }^{2 \S}$, Claudio Genchi ${ }^{3 \S}$
}

Address: ${ }^{1}$ Department of Veterinary Public Health and Veterinary Sciences, Faculty of Veterinary Medicine, University of Bari, Valenzano (Bari), Italy, ${ }^{2}$ Istituto Zooprofilattico Sperimentale delle Venezie, Legnaro (PD), Italy, ${ }^{3}$ Department of Veterinary Pathology, Hygiene and Public Health, University of Milan, Milan, Italy

Email: Domenico Otranto* - d.otranto@veterinaria.uniba.it; Gioia Capelli - gcapelli@izsvenezie.it; Claudio Genchi - claudio.genchi@unimi.it ${ }^{\S}$ These authors contributed equally to this work

${ }^{*}$ Corresponding author

from 4th International Canine Vector-Borne Disease Symposium Seville, Spain. 26-28 March 2009

Published: 26 March 2009

Parasites \& Vectors 2009, 2(Suppl I):S2 doi:10.1 I86/1756-3305-2-SI-S2

This article is available from: http://www.parasitesandvectors.com/content/2/SI/S2

(c) 2009 Otranto et al; licensee BioMed Central Ltd.

This is an Open Access article distributed under the terms of the Creative Commons Attribution License (http://creativecommons.org/licenses/by/2.0), which permits unrestricted use, distribution, and reproduction in any medium, provided the original work is properly cited.

\begin{abstract}
Ecological and climatic changes, human and animal population dynamics are among the several factors that have favoured the spread or the (re)introduction and establishment of "novel" vector species and pathogens they transmit in previously disease-free geographical areas. As key examples of the changing pattern of distribution of canine vector borne diseases (CVBDs), the current distribution of canine leishmaniosis (CanL) by Leishmania infantum and dirofilariosis by Dirofilaria immitis causing heart worm disease (HW) in Italy is discussed on the basis of retrospective historical reports until the 90's and later on until 2009. For long time, D. immitis has been considered mainly present along the Po RiverValley and northward areas, while L. infantum in southcentral Italy and Sicily and Sardinia. Comparison of current available and historical data (up to 1989) confirms that $\mathrm{HW}$ and $\mathrm{CanL}$, although with different prevalence rates, have been changing their distribution patterns in Italy as a result of many biological and ecological factors, including those related to vector distribution and introduction of new species (e.g. the Asian tiger mosquito Aedes albopictus, a competent vector of D. immitis). New autochthonous foci of HW in southern Italy (i.e. Apulia and Calabria regions) have recently been reported.

Although analysing retrospective data may represent a difficult task, the "paradigm" about the dual distribution of HW and CanL in northern and southern Italy cannot yet be considered valid. The research needs for managing $\mathrm{HW}$ and $\mathrm{CanL}$ in previously uninfected areas are discussed.
\end{abstract}

\section{Background}

The global spread of parasitic arthropods and of canine vector borne diseases (CVBDs) have no more boundaries across the planet. The combination of several factors (e.g. ecological and climatic changes, human and animal population dynamics) may affect, to different extents, the 
occurrence and spread of CVBDs in different geographical areas $[1,2]$. Movement of people (for tourism, work, etc.) and increased exchange of goods through a range of types of transportation (e.g. containers, aircraft cargoes) may play a crucial role for the (re)introduction and establishment of "novel" vector species and pathogens in previously disease free areas [3]. Such was the case of the Asian tiger mosquito Aedes albopictus which is a competent vector of Dirofilaria immitis to dogs [4] and of West Nile virus, Japanese B encephalitis, Chikungunya virus and other arboviruses to humans [5]. This mosquito species has successfully spread through many areas of the world, including Italy, causing outbreaks of vector borne infections in animals and humans $[5,6]$.

However, the spread into a previous non-endemic geographic area of vectors and of pathogens they transmit may be favoured and facilitated by arthropod non-specific host preferences, biological life cycle, off-host ecology, feeding behavior, presence of competent hosts and adaptability to different environmental conditions [7-9]. Many arthropods (e.g. ticks, sandflies and mosquitoes) infest dogs both in urban and rural areas, being adapted to survive in indoor and outdoor environments, increasing the risk of emergence or re-emergence of certain metazoonotic diseases [2]. Obviously the occurrence and establishment of a CVBD is regulated by a complex chain of interactions among pathogens, vectors and the environment.

Historically, the distribution of canine leishmaniosis (CanL) by Leishmania infantum and dirofilariosis by $D$. immitis in Italy was considered to be "dual", being $D$. immitis mainly present along the Po River Valley and northward areas [10] and L. infantum in south-central Italy and Sicily and Sardinia [11]. As a consequence, for long time, clinicians and parasitologists living in southern and northern Italy have been more used to deal with CanL and dirofilariosis respectively. As key examples of changing pattern of distribution of CVBDs, here we discuss the current distribution of these diseases, which are regarded among the most important and severe CVBDs of zoonotic concern. More specifically, we describe the occurrence of autochthonous foci of dirofilariosis by D. immitis in southern Italy and of recently detected foci of $L$. infantum in northern Italy, discussing scenarios of changing distribution patterns of both infections throughout this country.

\section{Distribution of dirofilariosis and leishmaniosis in Europe}

Dirofilaria immitis and Dirofilaria repens represent the most important filarial species in Europe both because of their pathogenicity on dogs' health and because of their zoonotic potential [12]. D. immitis is the causative agent of heartworm disease (HW) (Figure 1) which is widespread

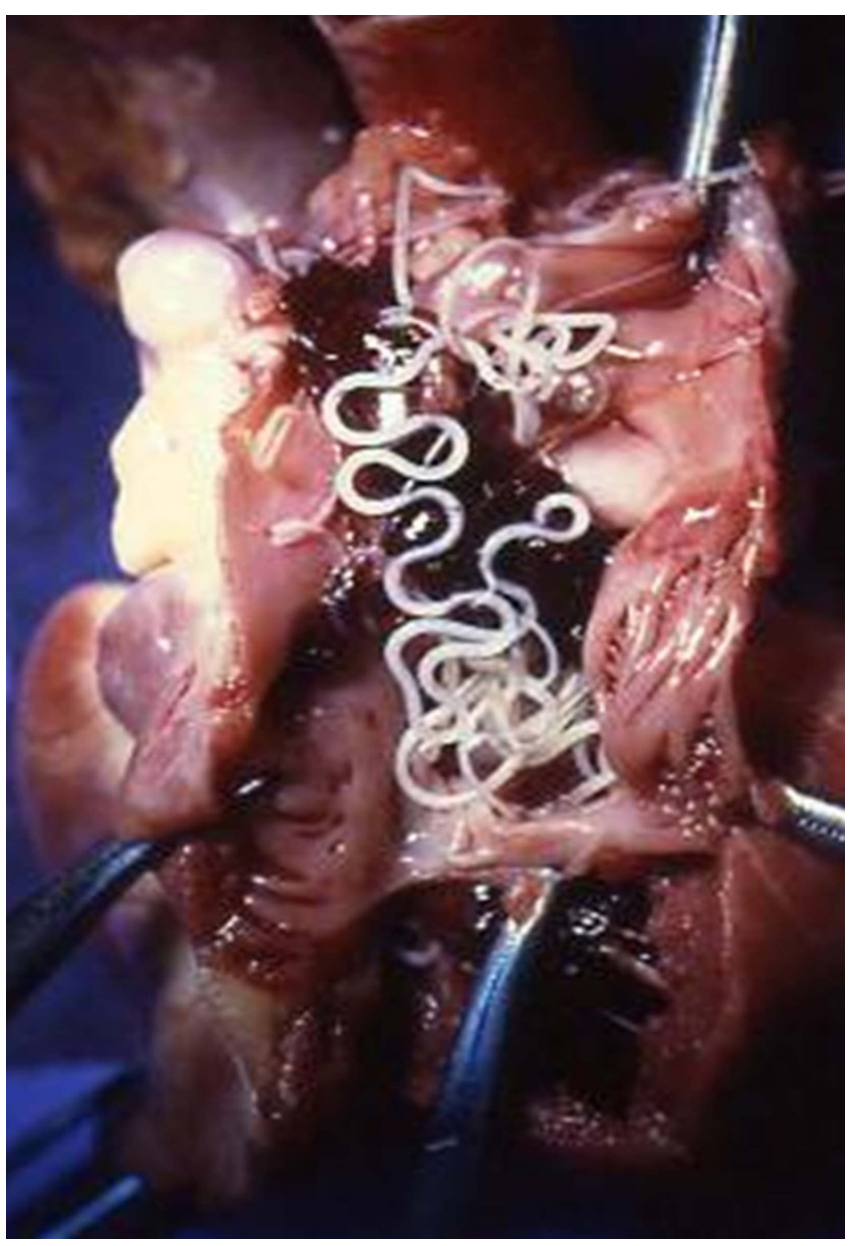

Figure I - Adult Dirofilaria immitis in the heart of a dog. Dirofilaria immitis adult worms at the dissection of a heart of a dog.

through tropical and temperate regions of the world, while $D$. repens causes a less pathogenic form, infesting subcutaneous tissues. Cases of human pulmonary dirofilariosis have been increasingly reported worldwide [13]. Indeed, D. repens adult worms occur in subcutaneous tissues [less frequently Acanthocheilonema (syn. Dipetalonema) reconditum, Acanthocheilonema (syn. Dipetalonema) grassii and Acanthocheilonema (syn. Dipetalonema) dracunculoides] or in the heart (D. immitis) of mammals (mainly primates and carnivores) and they are transmitted, as infective third stage larvae, by mosquitoes (Dirofilaria spp.) and other arthropods such as flies, lice and ticks [13].

Although dirofilariosis has for long time been considered a disease of veterinary concern and HW in dogs and cats might be a severe and often fatal disease in untreated animals, $D$. repens has been until recently recognized as an emerging metazoonosis in Europe (e.g. Italy $[14,15]$. Indeed, D. immitis is endemic in southern regions of 


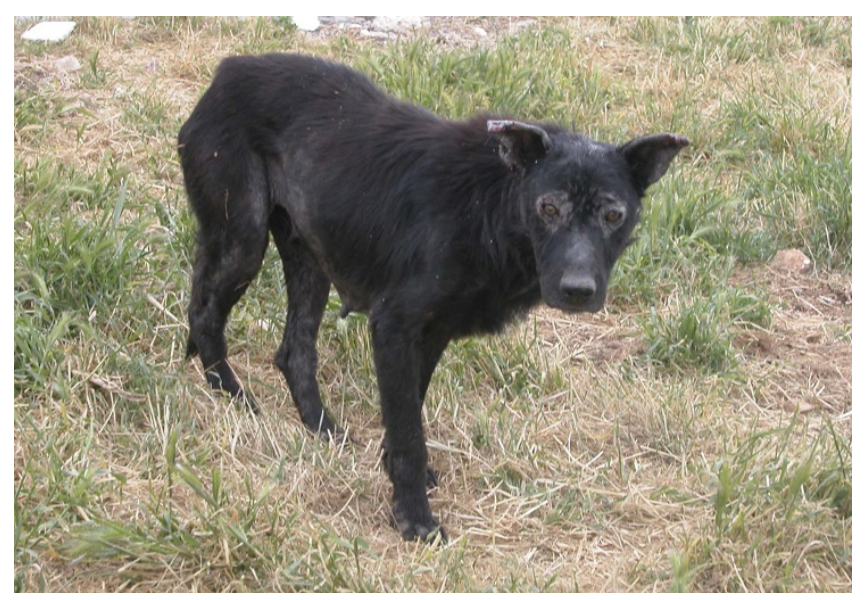

Figure 2 - Dog showing severe clinical signs of leishmaniosis.

A dog from southern Italy positive for Leishmania infantum both at the parasitological and serological tests presenting poor general conditions.

Europe even if, in the last decades, the number of reports in northeastern countries (e.g. Czech Republic, Serbia and Slovak Republic) is increasing [16-22]. Though the distribution of $D$. repens in Europe is less studied probably because of its reduced pathogenicity, this species is present in Italy, France and the eastern European countries [22].

Leishmania infantum, the causative agent of CanL in Mediterranean areas (Figure 2), is transmitted by different species of phlebotomine sandflies within the genus Phlebotomus $[23,24]$. The disease is considered to be one of the most important CVBDs of zoonotic concern, being widely distributed in Europe. CanL is endemic along the Mediterranean coast, from Portugal to Turkey, including Cyprus and Crete [3]. In this area, the prevalence of $L$. infantum infection varies widely, but might be as high as $80 \%$ [25]. More recently, infection by L. infantum in dogs has spread through northern Italy [26] and some countries of central Europe [27]. While in non- endemic areas, $L$. infantum infection mainly causes severe clinical forms [26], in endemic areas, most of the affected dogs may remain asymptomatic [28]. Nonetheless, asymptomatic animals might play a role in maintaining the infection in an endemic area by transmitting the infection to dogs and other receptive hosts including humans [29].

\section{Dirofilariosis and leishmaniosis: two diseases for two "Italys"}

For its geographical position (between $47^{\circ}-36^{\circ}$ north) and elongated shape, Italy may be represented as two countries. In particular, the Italian peninsula presents a large variety of habitats and environments, from the northern Alps through the Apennine Mountains to southern Italian and island regions. Accordingly, most of the inland northern areas have a continental humid climate whereas the coastal areas of the Liguria region and most of the peninsula, a Mediterranean temperate climate. The coastal regions have mild winters and warm and generally dry summers, although lowland valleys can be hot in summer.

The geographical distribution of dirofilariosis and leishmaniosis in northern and southern Italy respectively, although anecdotal, has reflected for a long time the different habitats and distribution of arthropod vectors. While the Culicidae vectors of $D$. immitis are mainly diffused and they develop during the summer months in humid climate areas of northern Italy [30], the coastal areas of the Liguria and the Mediterranean temperate regions of central and southern Italy are optimal to the development of different species of sandflies [31].

In Italy, canine dirofilarioses are transmitted by a number of culicid species (Table 1 ), which are mainly active during the late spring and summer [32]. The role of different Culicidae spp. as vectors of Dirofilaria spp. has been investigated by using insect dissection and molecular methods (Table 1) and their vectorial competence has been ascertained or suspected on the basis of the finding of DNA in different anatomical parts of mosquitoes [33].

The most common filarial species parasitizing dogs in Italy are $D$. immitis and $D$. repens (less frequently $A$. reconditum, A. grassii and A. dracunculoides). Canine dirofilariosis caused by $D$. immitis is considered endemic in northern regions with prevalence rates ranging from 22 to $80 \%[16,34]$. However, while D. repens was mainly widespread in southern regions, with the exception of Piedmont region in the north [34], the classical hyperendemic areas for D. immitis were along the Po River Valley [17]. The distribution and prevalence of dirofilariosis has been also studied in dogs from central and northern Italy, while epidemiological data on the occurrence of dirofilariosis by $D$. immitis in southern Italy are scant and limited to sporadic case reports. In the sole work ever conducted, out of 351 dogs parasitologically tested 63 (17.9\%) were microfilariemic in the Campania region [35]. As far as identification is concerned, $A$. reconditum was the most prevalent species identified $(16.5 \%)$ followed by $D$. repens (1.4\%) and D. immitis (0.5\%) [35].

In Italy, CanL caused by L. infantum is transmitted by different Phlebotomus species (Table 2 [31]). For long time, stable endemic foci of CanL by $L$. infantum have been reported from central and southern areas [11,36-38] with high percentages (up to $53.1 \%$ ) of serologically positive animals in southern regions [36]. Until the 1990s, CanL 
Table I - Proven or suspected Culicidae vectors of Dirofilaria immitis and Dirofilaria repens in Italy (North -N; South -S; Sicily -Si; Sardinia -Sa) [4,33,50].

\begin{tabular}{|c|c|c|c|}
\hline & Distribution & D. immitis & D. repens \\
\hline \multicolumn{4}{|l|}{ Anophelinae } \\
\hline Anopheles claviger* & N, S, Si, Sa & - & - \\
\hline A. maculipennis & $\mathrm{N}, \mathrm{S}, \mathrm{Si}$ & mol./f.c.s. & mol./f.c.s. \\
\hline \multicolumn{4}{|l|}{ Culicinae } \\
\hline Aedes albopictus & $\mathrm{N}, \mathrm{S}, \mathrm{Sa}$ & mol./f.c.s. & mol./f.c.s. \\
\hline Ae. cantans* & $N$ & - & - \\
\hline \multicolumn{4}{|l|}{ Ae. caspius* } \\
\hline & $\mathrm{N}, \mathrm{S}, \mathrm{Si}, \mathrm{Sa}$ & - & - \\
\hline Ae. cinereus & $N$ & mol./abd. & - \\
\hline Ae. geniculatus & $\mathrm{N}, \mathrm{S}, \mathrm{Si}, \mathrm{Sa}$ & mol./abd. & - \\
\hline Ae. detritus & $\mathrm{N}, \mathrm{S}, \mathrm{Si}, \mathrm{Sa}$ & mol./abd. & - \\
\hline Ae. punctor & $\mathrm{N}, \mathrm{S}$ & mol./abd. & - \\
\hline Ae. vexans* & $\mathrm{N}, \mathrm{S}, \mathrm{Si}, \mathrm{Sa}$ & - & - \\
\hline Coquillettidia richiardii* & N, S, Si, Sa & mol./f.c.s. & - \\
\hline Culiseta annulata* & $\mathrm{N}, \mathrm{S}, \mathrm{Si}, \mathrm{Sa}$ & - & - \\
\hline Culex modestus & $\mathrm{N}, \mathrm{S}, \mathrm{Si}, \mathrm{Sa}$ & mol./abd. & - \\
\hline C. pipiens & $\mathrm{N}, \mathrm{S}, \mathrm{Si}, \mathrm{Sa}$ & mol./f.c.s. & mol./f.c.s. \\
\hline C. territans* & $\mathrm{N}, \mathrm{S}$ & - & - \\
\hline C. torrentium & $\mathrm{N}$ & mol./abd. & - \\
\hline
\end{tabular}

* Culicidae spp. reported in Italy and suspected vectors of Dirofilaria spp. [33]. Evidence about the competence of Culicidae as vectors of Dirofilaria immitis and/or Dirofilaria repens in Italy relies on laboratory or field capture studies by dissection or PCR testing of field collected samples (mol./f.c.s.). PCR positive results of abdomens (mol./abd.), which however do not prove vector competence are also reported [4,33,50].

Table 2 - Proven or suspected Plebotominae vectors of Leishmania infantum in Italy (North -N; South -S; Sicily -Si; Sardinia -Sa) [23,24,3I].

\begin{tabular}{lc}
\hline Species & Distribution \\
\hline Phlebotomus ariasi & $\mathrm{N}$ \\
Phlebotomus neglectus & $\mathrm{N}, \mathrm{S}, \mathrm{Si}, \mathrm{Sa}$ \\
Phlebotomus perniciosus & $\mathrm{N}, \mathrm{S}, \mathrm{Si}, \mathrm{Sa}$ \\
Phlebotomus perfiliewi & $\mathrm{N}, \mathrm{S}, \mathrm{Si}$ \\
\hline
\end{tabular}

has been regarded as a sporadic disease in northern regions, mainly linked to animals with a history of travel to central and southern Italian regions [26].

\section{Changing distribution patterns: one Italy for two diseases}

In 1986 a review of the literature along with a questionnaire sent to public and private laboratories and clinics [39], defined as infected by D. immitis, $50 \%$ of the northern provinces and only $15 \%$ of the provinces of central and southern Italy. In the late 1980s and 1990s the HW infection showed a relevant prevalence increase in endemic areas compared with the 1970s [16]. Later on $D$. immitis infection was recorded outside the main endemic area of the Po Valley, in provinces of north-eastern Italy previously regarded as non- endemic [40]. Similarly, in Piedmont, an extensive survey carried out in the 1990s
[34] reported a spread of both D. immitis and D. repens westward and south-westward of the traditional endemic area. In particular, D. immitis infection successfully established in hilly and pre-alpine areas as well in urban areas [34].

More recently, D. immitis has become endemic in central regions such as Tuscany, where the prevalence increased more than 7 -fold in 10 years [16], and Umbria which was considered a non- endemic area until 1999 [41,42]. Nowadays, HW infection is endemic in central regions (Toscana, Umbria) with prevalences ranging from 1 to $21 \%$ [41-43]. In the latter case, similarly to that recorded in Piedmont region [34], it was observed that where an increase of prevalence and dispersion of $D$. immitis and $D$. repens was recorded, the first species spread much extensively and rapidly than $D$. repens in the same timerange. In the Lazio region, where only $D$. repens infection was recorded [43], D. immitis was recently found for the first time in culicid vectors [32]. Interestingly, both species have been also detected for the first time in autochthonous dogs living in another previously Dirofilaria-free region of central Italy, i.e. Abruzzo, close to Umbria and Lazio regions [44].

In Sardinia, a non-endemic area until 1960s, canine dirofilarioses have shown an increasing pattern of 
prevalence with peaks up to $17 \%$ [45] and cases have also been also reported in Sicily. [46].

While the distribution and prevalence of dirofilariosis has been widely studied in dogs from central and northern Italy, epidemiological data on the occurrence of dirofilariosis by $D$. immitis in southern Italy are scant [35] and limited to sporadic case reports. In a recent survey [47], from January 2005 to January 2008 a total of 1447 autochthonous dogs were sampled from 4 different areas of southern Italy (Apulia and Calabria regions) and grouped as follows: 404 dogs from the Bari municipal kennel for stray dogs (located in a urban area -site A), 421 dogs from the Ginosa municipal kennel for stray dogs (located in a rural area -site B), 389 owned dogs living in Bari, Lecce and Taranto municipalities, (side C) (Apulia region) and 233 dogs from the Cassano Jonico municipal kennel for stray dogs, Calabria region (site D). Animals from site $\mathrm{C}$ presented clinical signs related to canine HW infection while all other animals did not. All serum samples were examined by a commercial Canine Heartworm Test Kit (Idexx Laboratories ${ }^{\circledR}$ ) to detect D. immitis antigens, while blood from animals of sites $\mathrm{C}$ and $\mathrm{D}$ underwent parasitological examination by modified Knott method to detect microfilariae. After serological examination, 2 animals (one for each of sites $\mathrm{A}$ and $\mathrm{B}$ ) and 8 from sites $\mathrm{C}$ and $\mathrm{D}$ were diagnosed positive for the D. immitis. After parasitological examination, 4 animals were positive for microfilaria in both sites $\mathrm{C}$ and $\mathrm{D}$. Hence, percentages of positivity referring to both parasitological and serological tests were: $0.24 \%$ from site $\mathrm{A}, 0.23 \%$ from site $\mathrm{B}, 2.57 \%$ from site $\mathrm{C}$ and $3.43 \%$ from site D. Out of the total number of 20 positive dogs $(1.61 \%$ of the whole study population), 18 dogs were positive for $D$. immitis and 2 for $D$. repens.

The distribution of CanL in Italy has been revised from 1910 to 1983 [11]. Since the 1990s there has been an increase in the number of cases of CanL reported in Italy. Furthermore, new foci of CanL have been detected in northern regions, previously regarded as non-endemic [26]. The spreading of CanL northward in Italy has been assessed on the basis of recent analysis of human and dog cases of leishmaniosis recorded as well on the retrospective literature analysis of CanL. Seven leishmaniosis autochthonous foci were retrospectively identified from 1990 to 2002, whereas prospective investigations in the following years in dogs, identified other 16 possible foci all over northern regions, with low cumulative prevalence $(2.1 \%)$ either from serological tests or as clinical cases [26]. Data were also confirmed by phlebotomine sandfly records with four vector species identified. In particular, Phlebotomus perniciosus and Phlebotomus neglectus were the most represented species whose population have increased in density in northern Italy when compared with historical data [26]. In north-eastern Italy, new imported cases of CanL are regularly notified outside the original area of first infection, and established foci have been recently detected [48].

\section{Final considerations and research needs}

Comparison of historical (up to 1989) and current available data (1999-2009) confirms that HW and CanL, although with different prevalence rates, have been changing their distribution patterns in Italy (Figures 3 and 4) as a result of many biological and ecological factors (e.g. vector distribution, dog movements, improved diagnostics, higher awareness of researchers and practitioners).

Thus, despite the complexity in analysing retrospective data (e.g. difficulties in retrieving local reports published on national journals, differences in diagnostic tools and methodologies employed in different surveys), the "paradigm" about the dual distribution of HW and CanL in northern and southern Italy cannot be considered valid anymore. In fact, in addition to the likely tendency toward the spreading of HW in northern countries, there has been recorded an increasing number of reports in southern Italy and islands. As a consequence, canine dirofilariosis cannot anymore be considered as confined to northeastern [17] and central regions of the peninsula [42] because of its presence in southern Italy (even if with low prevalence). Whether there will be an expansion of HW infection over future years it is difficult to predict and infection foci need to be constantly monitored.

Without any doubt, the increase in the prevalence in previous endemic areas and the colonization of contiguous environments has been due to an increased density of the vectors and to a change in the composition of mosquito population (i.e. a predominance of mosquito species more efficient in Dirofilaria spp. transmission). A pivotal role in this process has probably been played by spreading of Ae. albopictus through Italy [49]. Indeed, since its introduction in 1990 Ae. albopictus adapted well to the relatively low winter temperatures of Italy by rapidly increasing its populations through the country, developing insects generations over the whole year in central and southern regions and overwintering as eggs in colder northern regions [49]. The spread of Ae. albopictus populations, coupled with its proven role as a suitable biological vector of both $D$. repens and $D$. immitis under experimental and field conditions [32,50-52], may further account for the current wide distribution of dirofilarioses.

New epidemiological investigations should also be addressed on the occurrence of the infection in canine populations in southern Italy. In addition, entomological surveys should be carried out to estimate the occurrence of the vectors of $D$. immitis and to monitor the expansion 


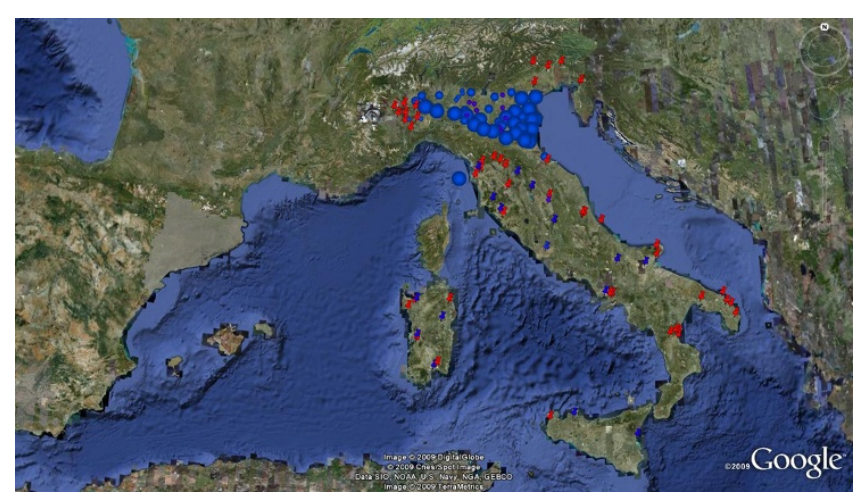

Figure 3 - Current distribution of Dirofilaria immitis in Italy.

Foci of canine dirofilariosis by Dirofilaria immitis until the 1990s in the endemic area of the Po Valley (blue dots) and outside the endemic area (blue pushpin). New foci (red pushpin) reported in non-endemic areas after the 1990s until 2009.

of the small foci of dirofilariosis in the Apulia and Calabria regions that have been here presented. The above information, along with continuing veterinary education, will possibly avoid the spreading of the disease in southern Italy.

Similarly, the reports of CanL here reviewed, when compared with historical data, confirm the likely expansion of $L$. infantum infection in northern Italy which now should be considered an endemic area. Given the widespread presence of the $L$. infantum domestic reservoir and the presence of infected dogs from endemic areas (due to enhanced and facilitated animal movements from endemic to non- endemic areas) Phlebotominae vectors had probably played a main role in spreading the infection in northern area of Italy. The increasing of population density rate and the expansion of $P$. perniciosus and $P$. neglectus was confirmed by comparing recent entomological surveys with available historical data [26]. The spreading of sandfly populations has been mainly due to shortening of larval development and extension of breeding seasons as an effect of increased temperatures [53]. The above phenomena might have ultimately contributed in favouring the establishment into previously free areas or in increasing insect density into already colonized areas of phlebotomine competent species of L. infantum and might represent an important issue to be considered while predicting the spreading of sandflies northward through central European continental countries.

As a further issue, new tools for monitoring and diagnosing CVBD (molecular technologies, mathematical models, remote sensing and geographical information

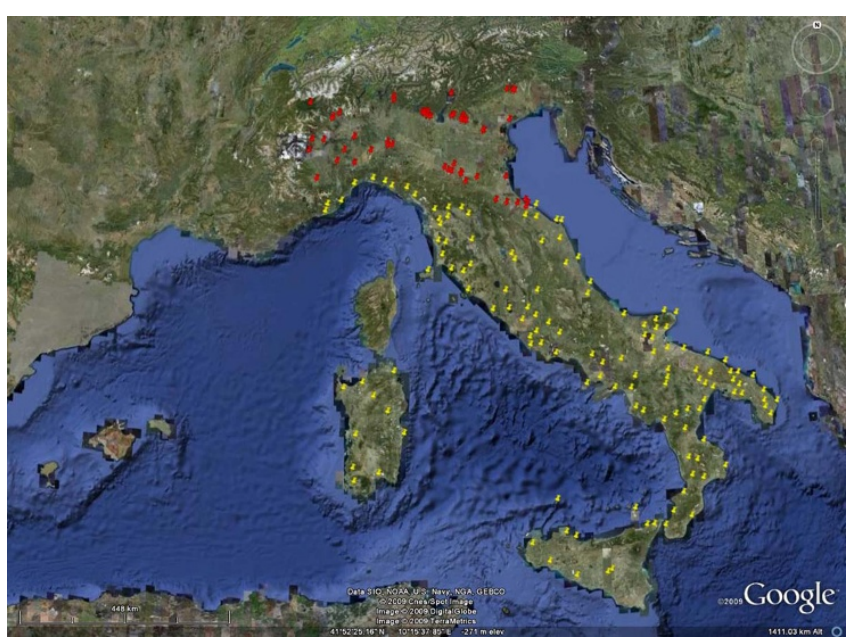

Figure 4 - Current distribution of Leishmania infantum in Italy before and after 1989.

Foci of canine leishmaniosis until the 1990s (yellow pushpin) in endemic regions of central and southern Italy (no autochthonous cases in northern regions were reported). New foci (red pushpin) in non-endemic areas after the 1990s until 2009 based on the report of autochthonous infected dogs and concomitant presence of competent sandflies.

systems) may be useful in studying current and predictive distribution of pathogens [54]. As an example molecular biology tools have been used to assess the prevalence and incidence of Leishmania species in a given area, thus providing new information on the genetic identity of pathogens and possibly tracking the probable origin of infection in non-endemic areas [55]. Also the use of recombinant antigens for serology (e.g. rK39 for L. infantum and S2-S16, rWSP for D. immitis) have refined and implemented our understanding of the epidemiology for many CVBDs by providing new data about their distribution [54].

As a consequence, maps on the occurrence of CVBD causing pathogens in different geographical areas [56] need to be continuously updated on the basis of national level reports to assess the risk of infection spreading. The occurrence of large numbers of asymptomatic dogs in CanL [28] and HW infected populations and the long incubation periods, in which they are able to infect sandflies and mosquitoes, should be considered as an important issues when planning control measures for both diseases.

Although in Italy the perception and the awareness of researchers and practitioners on many aspects of CVBD have increased over the last decade, many issues still need to be better investigated. These include basic knowledge 
on vector, pathogen and host interactions which would provide new information to manage CVBD in endemic areas reducing the risk of occurrence of new foci in non endemic zones. Under the above circumstances, monitoring the disease mainly in presence of stray untreated dogs is a necessity for planning control strategies for CVBDs. While stray dogs represent an easy feeding source for arthropods and reservoir of pathogens, the scant economic resources (which are further worsened by the global economic crisis), the current legislation that obliges the health public authorities to maintain municipal kennel for stray dogs (in which animals remain often untreated against ectoparasites), probably represent the major impairments toward the control of HW and CanL in Italy as well as in other Mediterranean countries.

\section{Competing interests}

The authors declare that they have no competing interests.

\section{Acknowledgements}

D.O. thanks Irene Canfora for her kind assistance during the ms. preparation. Riccardo P. Lia and Gabriella Testini (University of Bari, Italy) for contributing in some researches here described, Filipe-Dantas Torres (University of Bari, Italy) for some suggestions on the first drafting of the ms. and Giorgio Bossetti (Idexx Laboratories ${ }^{\circledR}$, Italy) for supporting the survey carried out in southern Italy. G.C. thanks Giulia Simonato for her assistance in elaborating maps.

This article is published as part of Parasites \& Vectors Volume 2 Supplement I, 2009: Proceedings of the 4th International Canine Vector-Borne Disease Symposium. The full contents of the supplement are available online at http://www.parasitesandvectors.com/supplements/2/SI.

Publication of the supplement has been sponsored by Bayer Animal Health $\mathrm{GmbH}$.

\section{References}

I. Medlock JM, Barras I, Kerrod E, Taylor MA, Leach S: Analysis of climatic predictions for extrinsic incubation of Dirofilaria in the United Kingdom. Vector Borne Zoonotic Dis 2007, 7:4-14.

2. Otranto D, Dantas-Torres F, Breitschwerdt EB: Managing canine vector-borne diseases of zoonotic concern: part one. Trends Parasitol, in press.

3. Shaw SE, Day, MJ: Arthropod-borne Infectious Diseases of the Dog and Cat. London: Manson Publishing; 2005.

4. Cancrini G, Frangipane di Regalbono A, Ricci I, Tessarin C, Gabrielli S, Pietrobelli M: Aedes albopictus is a natural vector of Dirofilaria immitis in Italy. Vet Parasitol 2003, I I 8:195-202.

5. Scholte EJ, Schaffner F: Waiting for the tiger: establishment and spread of the Aedes albopictus mosquito in Europe. In Emerging Pests and Vector-Borne Diseases in Europe. Volume I. Edited by Takken W, Knols BGJ. Wageningen, Netherlands: Wageningen Academic Publishers; Wageningen, 2007:24I-260.

6. Rezza G: Chikungunya and West Nile virus outbreaks: what is happening in north-eastern Italy? Eur J Public Health, in press.

7. Root TL, Price JT, Hall KR, Schneider SH, Rosenzweig C, Pounds JA: Fingerprints of global warming on wild animals and plants. Nature 2003, 421:57-60.

8. Khasnis AA, Nettleman MD: Global warming and infectious disease. Arch Med Res 2005, 36:689-696.

9. Purse BV, Mellor PS, Rogers DJ, Samuel AR, Mertens PP, Baylis M: Climate change and the recent emergence of bluetongue in Europe. Nat Rev Microbiol 2005, 3: I 7I-I8I.

10. Genchi C, Di Sacco B, Cancrini G: Epizootiology of canine and feline heartworm infection in Northern Italy: possible mosquito vectors. In Proceedings of the American Heartworm Symposium 1992. Batavia, IL: American Heartworm Society, Edited by Soll MD; 1992:39-46.

II. Pozio E, Gradoni L, Gramiccia M: Canine leishmaniasis in Italy from 1910 to 1983. Ann Parasitol Hum Comp 1985, 60:543-553.

12. Genchi C, Simon F, Kramer LH: Dirofilariasis in humans: is it a real zoonotic concern? In Proceedings of the $30^{\text {th }}$ World Congress of the World Small Animal Veterinary Association; II-I4 May 2005; Mexico City

13. McCall JW, Genchi C, Kramer LH, Guerrero J,Venco L: Heartworm disease in animals and humans: a review. Adv Parasitol 2008, 66 : 193-285.

14. Pampiglione S, Rivasi F, Angeli G, Boldorini R, Incensati R, Pastormerlo $M$, Pavesi M, Ramponi A: Dirofilariasis due to Dirofilaria repens in Italy, en emergent zoonosis: report of 60 new cases. Histopathology 200 I, 38:344-354.

15. Pampiglione S, Rivasi F, Gustinelli A: Dirofilarial human cases in the Old World, attributed to Dirofilaria immitis: a critical analysis Histopathology 2009, 54:192-204.

16. Genchi C, Kramer LH, Prieto G: Epidemiology of canine and feline Dirofilariosis: a global view. In Heartworm infection in humans and animals. Edited by Simon F, Genchi C. Salamanca; 200I: |2|-|33.

17. Genchi C, Rinaldi L, Cascone C, Mortarino M, Cringoli G: Is heartworm disease really spreading in Europe? Vet Parasitol 2005, I 33: | 37- | 48.

18. Svobodova V, Misonova P: The potential risk of Dirofilaria immitis becoming established in the Czech Republic by imported dogs. Vet Parasitol 2005, I 28: I 37- I 40.

19. Svobodova Z, Svobodova V, Genchi C, Forejtek P: The first report of autochthonous dirofilariosis in dogs in the Czech Republic. Helminthol 2006, 43:242-245.

20. Babal P, Kobzova D, Novak I, Dubinsky P, Jalili N: First case of cutaneous human dirofilariosis in Slovak Republic. Bratisl Lek List 2008, 109:486-488.

21. Tasiæ A, Rossi L, Tasiæ S, Miladinoviæ-Tasiæ N, lliæ T, Dimitrijeviæ S: Survey of canine dirofilariasis in Vojvodina, Serbia. Parasitol Res 2008, 103:1297-1302.

22. Genchi C, Rinaldi L, Mortarino M, Genchi M, Cringoli G: Climate and Dirofilaria infection in Europe. Vet. Parasitol. 2009, in press.

23. Killick-Kendrick R: Phlebotomine vectors of the leishmaniases: a review. Med Vet Entomol 1990, 4:1-24.

24. World Health Organization. Control of the Leishmaniases: Technical Report Series, 793: I-I58, Geneva; 1990.

25. Baneth G, Koutinas AF, Solano-Gallego L, Bourdeau P, Ferrer L: Canine leishmaniosis -new concepts and insights on an expanding zoonosis: part one. Trends Parasitol 2008, 24:324-330.

26. Maroli M, Rossi L, Baldelli R, Capelli G, Ferroglio E, Genchi C, Gramiccia M, Mortarino M, Pietrobelli M, Gradoni L: The northward spread of leishmaniasis in Italy: evidence from retrospective and ongoing studies on the canine reservoir and phlebotomine vectors. Trop Med Int Health 2008, 13:256-264.

27. Schönian G, Mauricio I, Gramiccia M, Cañavate C, Boelaert M, Dujardin JC: Leishmaniases in the Mediterranean in the era of molecular epidemiology. Trends Parasitol 2008, 24:I35-142.

28. Otranto D, Paradies P, de Caprariis D, Stanneck D, Testini G, Grimm F, Deplazes P, Capelli G: Toward diagnosing Leishmania infantum infection in asymptomatic dogs in an area where leishmaniasis is endemic. Clin Vaccine Immunol 2009, 16:337-343.

29. Michalsky EM, Rocha MF, da Rocha Lima AC, França-Silva JC, Pires MQ, Oliveira FS, Pacheco RS, dos Santos SL, Barata RA, Romanha AJ, Fortes-Dias CL, Dias ES: Infectivity of seropositive dogs, showing different clinical forms of leishmaniasis, to Lutzomyia longipalpis phlebotomine sand flies. Vet Parasitol 2007, I 47:67-76.

30. Guerrero J, Ducos de la Hitte J, Genchi C, Rojo F, Gomez-Bautista M, Carvalho Valera M, Labarthe N, Bordini E, Gonzales G, Mancebo O, Patino F, Uribe LF, Samano R: Update on the distribution of Dirofilaria immitis in dogs from Southern Europe and Latin America. In Proceedings of the American Heartworm Symposium 1992. Batavia, IL:American Heartworm Society. Edited by Soll MD. 1992:3 I37.

31. Maroli M, Bigliocchi F, Khoury C: Sandflies in Italy: observations on their distribution and methods for control. Parassitologia, 1994, 36:25I-264. 
32. Cancrini G, Scaramozzino P, Gabrielli S, Di Paolo M, Toma L, Romi R: Aedes albopictus and Culex pipiens implicated as natura vectors of Dirofilaria repens in central Italy.J Med Entomol 2007 44:1064-1066.

33. Cancrini G, Gabrielli S: Vectors of Dirofilaria nematods: biology behaviour and host/parasites relationships. In Dirofilaria immitis and D. repens in dog and cat and human infections. Edited by Genchi $C$, Rinaldi L, Cringoli G. Napoli: Rolando Editore; 2007:49-58.

34. Rossi L, Pollono F, Meneguz PG, Gribaudo L, Balbo T: An epidemiological study of canine filarioses in north-west Italy: what has changed in 25 years? Vet Res Commun 1996, 20:308-3I5.

35. Cringoli G, Rinaldi L, Veneziano V, Capelli G: A prevalence survey and risk analysis of filariosis in dogs from the Mt. Vesuvius area of southern Italy. Vet Parasitol 200I, 102:243-252.

36. Brandonisio O, Carelli G, Ceci L, Consenti B, Fasanella A, Puccini V: Canine leishmaniasis in the Gargano Promontory (Apulia South Italy). Eur J Epidemiol 1992, 8:273-276.

37. Bongiorno G, Habluetzel A, Khoury C, Maroli M: Host preferences of phlebotomine sandflies at a hypoendemic focus of canine leishmaniasis in central Italy. Acta Trop 2003, 88:109-1 I6.

38. Paradies P, Capelli G, Cafarchia C, de Caprariis D, Sasanelli MT, Otranto D: Incidence of canine leishmaniasis in an endemic area of Southern Italy.J Vet Med B Infect Dis Vet Public Health 2006 53:295-298.

39. Pampiglione S, Poglayen G, Capelli G: Distribuzione geografica delle filariosi canine. Parassitologia 1986, 28:297-300.

40. Poglayen G, Martini M, Bomben L, Roda R: An updating of the occurrence of canine heartworm disease in northern Italy Vet Res Commun 1996, 20:303-307.

4I. Piergili Fioretti D, Diaferia M, Grelloni V, Maresca C: Canine filariosis in Umbria: an update of the occurrence one year after the first observation of autochthonous foci. Parassitologia 2003, 45:79-83.

42. Mortarino M, Musella V, Costa V, Genchi C, Cringoli G, Rinaldi L: GIS modeling for canine dirofilariosis risk assessment in centra Italy. Geospat Health 2008, 2:253-26I.

43. Scaramozzino P, Gabrielli S, Di Paolo M, Sala M, Scholl F, Cancrini G: Dog filariosis in the Lazio region (Central Italy): first report on the presence of Dirofilaria repens. BMC Infect Dis 2005, 26:75.

44. Paoletti B, Traversa D, Guglielmini C, lorio R, Bazzocchi C, Pampurini F, Boari A: Autochthonous canine dirofilariosis in Abruzzo region of central Italy. In Proceedings of the Congress of the Italian Society of Parasitology: I 8-2 I June 2008; Pisa. Edited by Lombardo; 2008.

45. Scala A, Varcasia A, Genchi C, Capelli G: Epidemiology of dog filariosis in Sardinia island, Italy. In Proceedings of the 20th International Conference of the World Association for the Advancement of Veterinary Parasitology: 16-20 October 2005; Christchurch, New Zealand, 2005:246.

46. Giannetto S, Pampiglione S, Santoro V, Virga A: Research of canine filariasis in Trapani province (western Sicily). Morphology on SEM of male Dirofilaria repens. Parassitologia 1997, 39:403-405.

47. Otranto D, Lia RP, Testini G, Britti D, Puntorieri EP, Genchi C: Autochthonous cases of canine dirofilariosis in Southern Italy. In Proceedings of the Congress of the Italian Society of Parasitology: I8-2I June 2008; Pisa. Edited by Lombardo; 2008.

48. Cassini R: Aspetti epidemiologici e rischi zoonosici delle malattie trasmesse da vettori: babesiosi e leishmaniosi in Italia nord-orientale. PhD thesis, Faculty of Veterinary Medicine, University of Padua, 2008. URL: http://paduaresearch.cab. unipd.it/794/

49. Romi R, Majori G: An overview of the lesson lerned in almost 20 years of fight against the "tiger mosquito". Parassitologia 2008, 50:117-119.

50. Cancrini G, Romi R, Gabrielli S, Toma L, Di Paolo M, Scaramozzino P. First finding of Dirofilaria repens in a natural population of Aedes albopictus. Med Vet Entomol 2003, I 7:448-45I.

5I. Masetti A Rivasi F Bellini R. Mosquito-based survey for the detection of flaviviruses and filarial nematodes in Aedes albopictus and other anthropophilic mosquitoes collected in northern Italy. New Microbiol 2008, 3 I:457-465.

52. Pietrobelli M: Importance of Aedes albopictus in veterinary medicine. Parassitologia 2008, 50:1 I3-II5.

53. Killick -Kendrick R: Leishmaniasis -an English disease of the future? Trop Med Int Health 1996, 4:5.

54. Otranto D,Wall R: New strategies for the control of arthropod vectors of disease in dogs and cats. Med Vet Entomol 2008, 22 291-302.
55. Schönian G, Mauricio I, Gramiccia M, Cañavate C, Boelaert M Dujardin JC: Leishmaniases in the Mediterranean in the era of molecular epidemiology. Trends Parasitol 2008, 24: I35-I42.

56. Trotz-Williams LA, Trees AJ: Systematic review of the distribution of the major vector-borne parasitic infections in dogs and cats in Europe. Vet Rec 2003, 152:97-105. 